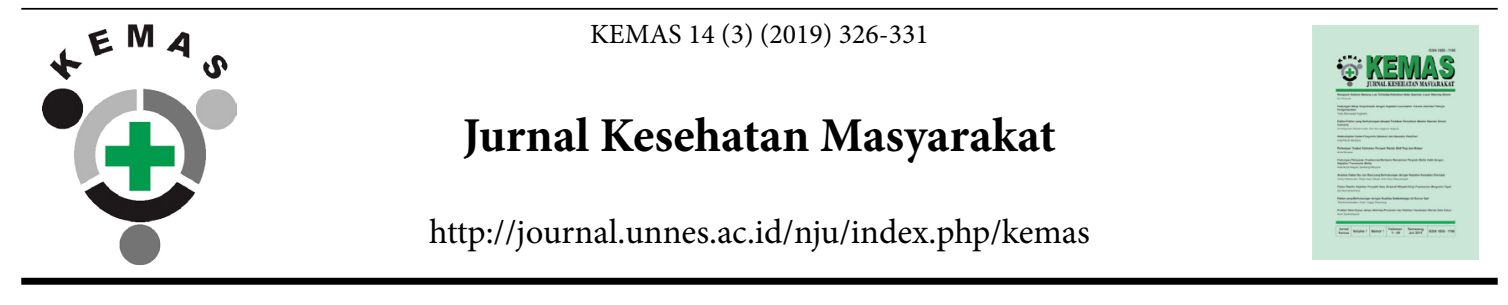

\title{
Description of School Health Development Index (SHDI) in Junior High Schools in Buleleng Regency - Bali
}

\author{
Made Agus Dharmadi ${ }^{\circledR}$, Ni Nyoman Mestri Agustini ${ }^{2}$ \\ ${ }^{1}$ Faculty of Sports and Health, Universitas Pendidikan Ganesha, Indonesia \\ ${ }^{2}$ Faculty of Medicine, Universitas Pendidikan Ganesha, Indonesia
}

\begin{tabular}{l} 
Article Info \\
\hline Article History: \\
Submitted December 2017 \\
Accepted January 2018 \\
Published March 2019 \\
\hline Keywords: \\
SHDI, Health \\
Development, \\
Junior High School \\
\hline DOI \\
https://doi.org/10.15294/ \\
kemas.v14i3.12389
\end{tabular}

\begin{abstract}
Synergism in the field of health and education is strongly needed and urgent in order to attain a comprehensive education goal of intelligent and healthy people both physically and mentally according to the mandate of the 1945 Constitution. Based on the observation in Junior High Schools in Buleleng, We found that there were a lack synchronization between vision, missions, and the planned programs in the schools, limited cleaning facilities, and an implicitly lack of healthy lifestyle of the school residents. This research aimed to describe the School Health Development Index (SHDI) at the level of secondary schools in Buleleng Regency in 2017. The sample of the research were obtained from 10 junior high schools/JHS (SMP) in Buleleng Regency. We used a method of quantitative description following observations, documentation studies, and interviews. Based on the result and discussion, we concluded that: 1) SHDI of SMP in Buleleng Regency was categorized as mid-low (0.62), with minimal value of 0.51 and largest value of 0.78 . The highest index was obtained by SMP 1 Singaraja and the lowest index was obtained by SMP Bhaktiasa Singaraja, 2) most of the schools did not include healthy value explicitly in the schools' vision and missions, 3 ) most of the schools operated limited number of programs on health and did not include written reports on their programs, 4) the condition of facilities and infrastructures were sufficient, there were several schools having no warehouse, and the food products in cafeterias were not controllable yet especially for the unlicensed food products (without BPOM logo), 4) the school residents' healthy lifestyle was good enough especially for the teachers and the students.
\end{abstract}

\section{Introduction}

Success in the public health was a construction formed by collaboration between environment, health via scientists working in the social field, economy, and government (Reis, et al, 2014). The education world, particularly through school organization became the front guard in efforts to achieve welfare and health either individually or collectively that presented a reflection of the whole community because it consisted of teachers, school principal, students, staffs, etc., which were parts of the community.
Lately, the government has implemented synergism between the field of health and education that was instrumental and urgent in efforts to achieve the comprehensive goal of education in building intelligent and healthy people physically and mentally according to the mandate of the 1945 Constitution (Kemenkes, 2014). Students were future generations as well as the successors and the assets of the nation, therefore the health education needed to be implemented at school age, because the school had an important role in transferring 
information of health to the students and the public, it is because healthy lifestyle was the habit that are needed to be initiated by parents, children, and teachers at school (Adisasmito, 2010). The development in health should be implemented in every level of the nation, especially in education. Health should be oriented towards Global Health, therefore it could build health comprehensively and broadly for all (Ooms et al, 2014).

A development of quality school was presumed to experience setbacks in which the requirements in the regulation of new school constructions were often overlooked, for example the space area for the school was minimal, the building layout was narrow, the location of the school was even in a crowded and slum settlement. In addition, recently the school decided to attract as many students as possible in order to fulfil the funding resource and likely to acquire more recognition than the other schools instead of improving the quality. Therefore, it become one of the reasons why the schools need to be improved in quality in the context of the healthy schools in managing regulations, programs, facilities and infrastructures in supporting the effort on integrated school health development.

The Junior High School (SMP) level was the level focused in this research, considering that the students in SMP level were categorized as teenagers, who were psychologically unstable both in thinking and in action. Based on the observation, the researchers found that in SMPs in Buleleng, there was a lack of synchronization between vision, missions, and the planned programs of the schools, there were also limited cleaning facilities, and indirectly a lack of healthy lifestyle of the schools' residents. Therefore, the students needed a control, a comprehension, a habituation and a positive experience in health to carry out their future.

A research by Dharmadi (2016) showed that the dimension and the indicator of SHDI consisted of the following rule: 1) Healthy school is strongly emphasized for each school in Buleleng Regency either at the level of elementary school, junior high school, or senior high school; 2) A comprehension on School Health Development Index (SHDI) of the teachers in charge of UKS (Unit Kesehatan
Sekolah/School Health Unit) in elementary schools, junior high school, and senior high school was still low; 3) SHDI in each school was vital to understand and to measure the health degree in each school in Buleleng Regency; 4) Dimension of SHDI based on analysis were: a) School regulation, b) School Program, c) facility and infrastructure which consists of indicators of availability of vision and missions, school buildings (cleanliness of air ventilations, lightings, non-slippery floor, standard of space area, cleaning facilities, toilet, etc.), d) Behavior/ lifestyle of the school residents, 5) Availability of guide book of SHDI was one of the references in achievement of school health development.

Furthermore, another research (Dharmadi, 2017) found a feasible instrument of SHDI, therefore it was proper to be used to obtain a description of school health development index which consisted of four principle components, namely 1) School regulation, 2) School Program, 3) Facility and infrastructure, and 4) Healthy lifestyle of the school residents.

According to the background and the result of the prior researches and in order to develop a grand strategy based on evidence, hence the research entitled School Health Development Index (SHDI) in Junior High Schools in Buleleng Regency-Bali was urgent to be conducted immediately.

\section{Methods}

The research method was descriptivequantitative, through observation, literature study, and interviews to obtain a description of SHDI in junior high schools in Buleleng Regency. We determined the sample by purposive sampling by considering the private or state status of the schools. The sample size in this research included 10 Junior High Schools (7 State Schools and 3 Private Schools) in Buleleng Regency. We used SHDI Instrument that consisted of several components: school regulation, school program, facility and infrastructure, and healthy lifestyle of the schools' residents (Dharmadi, 2017). We analyzed the data obtained in this research quantitatively to determine the indexation.

\section{Results and Discussions}

This research was a survey study in which the result obtained was the data from schools 
Table 1. Score of SHDI SMP in Buleleng Regency $(\mathrm{N}=10)$

\begin{tabular}{lllllll}
\hline No & School Name & \multicolumn{5}{c}{ COMPONENT OF SHDI } \\
\cline { 3 - 7 } & & $\begin{array}{l}\text { School } \\
\text { Regulation }\end{array}$ & $\begin{array}{l}\text { School } \\
\text { Program }\end{array}$ & $\begin{array}{l}\text { Facility and } \\
\text { Infrastructure }\end{array}$ & $\begin{array}{l}\text { Residents } \\
\text { Lifestyle }\end{array}$ & Total \\
\hline 1 & SMP 1 Sksada & 1.4 & 2.7 & 2.7 & 2.7 & 9.5 \\
2 & SMP 4 Singaraja & 1.4 & 2.6 & 2.5 & 2.8 & 9.3 \\
3 & SMP Mutiara & 1.4 & 2.1 & 2.4 & 2.8 & 8.7 \\
4 & SMP 3 Singaraja & 1.5 & 2.3 & 2.3 & 2.4 & 8.5 \\
5 & SMP Lab & 1.5 & 2.8 & 2.8 & 2.5 & 9.6 \\
6 & SMP 6 Singaraja & 1.4 & 3 & 2 & 2.8 & 9.2 \\
7 & SMP 1 Singaraja & 1.5 & 2.8 & 2.9 & 3 & 9.2 \\
8 & SMP 1 Sawan & 1.5 & 2.4 & 1.9 & 2.7 & 8.5 \\
9 & SMP 2 Singaraja & 1.5 & 2.4 & 2.6 & 2.6 & 9.1 \\
10 & SMP Baktiasa & 1.4 & 2 & 2.1 & 2.6 & 8.1 \\
\hline
\end{tabular}

Source: Data tailored by SHDI Instrument in 2017

on their school health condition in term of regulations, facilities and infrastructures, programs on health, and the healthy lifestyle of the schools' residents. We obtained data by using a feasibly arranged instrument based on the result of experiment in the previous study. However, prior to data collection, the researchers performed a one-day training to the team that was responsible in data collection about how to use the instrument. Resulted from the training, the team members totally $100 \%$ understood how to use the instrument to collect data, this result was supported by the result of short interview with each team member in the end session of training.

In more detail, what was described in Table 1 would be showed in a bar chart by presenting detail position of SHDI Score in SMPs in Buleleng Regency in various different colors, whereas it would be easy to view the score of each component that consisted of school regulation, school program, facility and infrastructure, and healthy lifestyle of the school residents. The following Figure 1 would

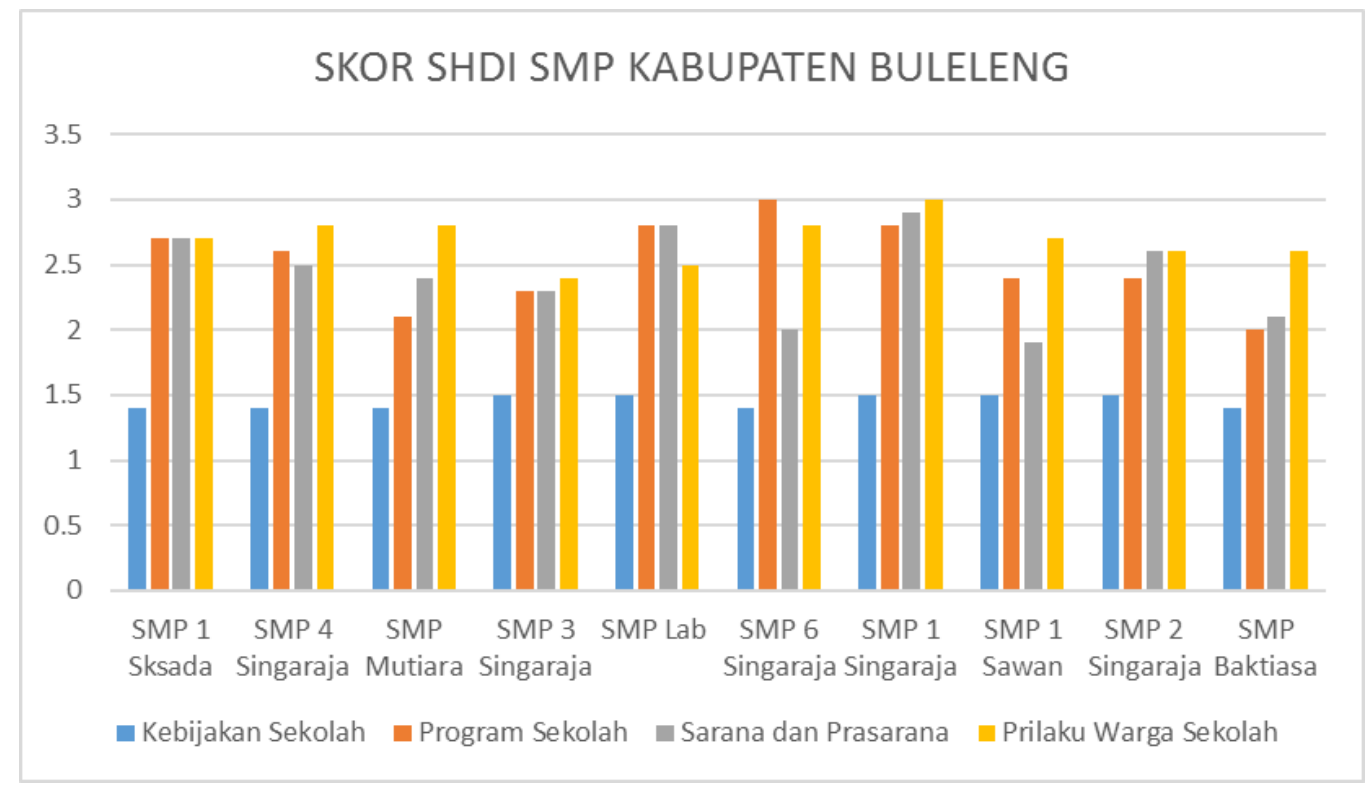

Figure 1. Score of SHDI in SMPs in Buleleng Regency 
present the detailed information.

Based on the data in Table 1 and Figure 1 , we found that the component of School regulation consisted of vision, missions, and goals showed a low score from the highest score that was 3 , almost all the schools brought a range of score about 1.4-1.5. It showed that in this component, the schools did not clearly involve health aspects as the vision, missions, and goals. Whereas in the component of program, the result showed that $10 \%$ of the schools brought a high score in the highest score of 3 , and the rest $90 \%$ of the schools brought a low score ranged from 2 to 2.8. This result indicated that in the component of program, the SMPs in Buleleng Regency neither already implement nor record the programs on health. Furthermore, in the component of facility and infrastructure, 10\% of the samples brought a score of 1.9, and the rest $90 \%$ of the samples brought a score ranged from 2 to 2.8. This result showed that there were still lacks of in the facilities and infrastructures such as cleanliness and health of the UKS, cafeteria, the principal room, toilet, teacher room, warehouse, etc. Then, the last component of the lifestyle showed that $10 \%$ of the samples obtained a score of 3 (excellent) and $90 \%$ of the samples obtained a score ranged from 2 to 2.9. This showed that the lifestyle of the schools' residents was already good implemented by several school residents such as teachers, students, parents, etc.

After obtaining the total score from each component, we calculated the index using index formula with the result as presented in the Table 2.

Table 2. Value of SHDI Index in SMPs in Buleleng Regency

\begin{tabular}{lllll}
\hline \multirow{2}{*}{ NO } & \multirow{2}{*}{ School Name } & \multicolumn{3}{c}{ SHDI } \\
\cline { 3 - 5 } & & Total Score & Max Score & Value Of Index \\
\hline 1 & SMP 1 Sksada & 9.5 & 12.0 & 0.69 \\
2 & SMP 4 Singaraja & 9.3 & 12.0 & 0.66 \\
3 & SMP Mutiara & 8.7 & 12.0 & 0.59 \\
4 & SMP 3 Singaraja & 8.5 & 12.0 & 0.56 \\
5 & SMP Lab & 9.6 & 12.0 & 0.70 \\
6 & SMP 6 Singaraja & 9.2 & 12.0 & 0.65 \\
7 & SMP 1 Singaraja & 9.2 & 12.0 & 0.78 \\
8 & SMP 1 Sawan & 8.5 & 12.0 & 0.56 \\
9 & SMP 2 Singaraja & 9.1 & 12.0 & 0.64 \\
10 & SMP Baktiasa & 8.1 & 12.0 & 0.51 \\
\hline \multicolumn{2}{l}{ Mean of SHDI in SMPs } \\
\hline
\end{tabular}

Source: Data tailored using SHDI Instrument in 2017

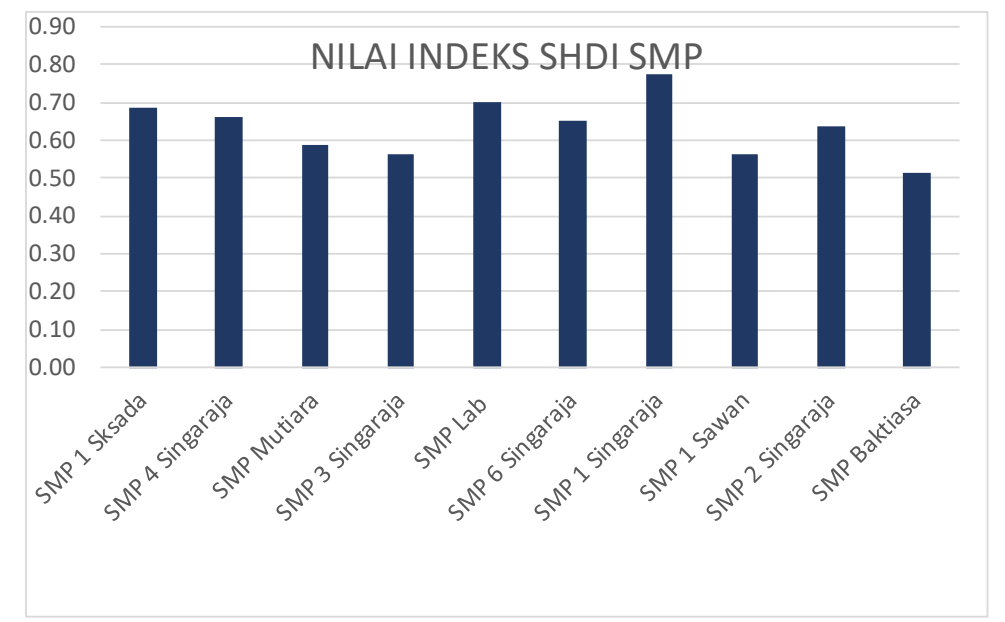

Figure 2. Value of SHDI index in SMPs in Buleleng Regency 
In more detail, what was described in Table 2 would be presented in bar chart that showed the detail position of the index score of SHDI in SMPs in Buleleng Regency therefore we could visualize each index of SMPs in Buleleng Regency. The following was the Figure 2.

Data in Table 2 and Figure 2 showed that generally the average index of SHDI in SMPs was 0.63 (mid-low category), with the lowest index of 0.51 that was of SMP Bhaktiasa Singaraja, and the highest index of 0.78 that was of SMP 1 Singaraja. The quantification of data was supported by the data from interviews to the teachers responsible to provide information toward the desired-to-obtain data of SHDI.

The interviews resulted: firstly, almost of the school regulations were not explicitly authorizing the health school development. It was reflected from the lack of health aspect in the vision and missions. The school authorities assumed that the health aspects had been consisted in the vision and missions, therefore there was no need to write down the health element. In addition, the school authorities stated that the vision and missions referred to the regulation from Education Authority, and they should have not be different/deviated from the guidance. With the availability of regulation on health, the schools could prevent and control the transmission of several diseases/ negative influences such as HIV, Malaria, Tuberculosis (TB), Drug abuse, smoking habit in the community to support WHO program target in the future (Sridhar \& Gostin, 2014). However Waltona, W and Signalb (2013) stated that the role of school regulation was essential in minimalizing undernutrition or obesity occurrence among students.

Second; Programs on health of in SMPs in Buleleng Regency has been quite good, such as routine individual hygiene, cleanliness competitions, exercises, etc. The program implementation was good enough; however, the written reports to record the programs were unavailable in almost all the schools (SMPs) in Buleleng. This indicated a slightly poor quality because that the reports were useful for an analysis and a follow-up in term of evaluation was unavailable too. This result was consistent with the suggestion of Ko et al., (2014), that stated that to reduce mortality we should conduct an intervention on health in community through health education (at school).

Third; the facilities and infrastructures that consisted of several indicators such as class room, UKS room, warehouse, toilet, cafeteria, pray room, etc. were well enough available. However, from the indicators, the researchers found that there were many schools did not have warehouses, some of the schools did not have UKS room, as well as proper toilets and appropriate/BPOM-licensed food products in cafeteria. Based on the information, the cause were the limited space area and the overlooked recommendations by the food merchants for appropriate foods products. The appropriate facilities and infrastructures were primarily vital to be accomplished.

Fourth; the healthy lifestyle of the schools' residents consisting of the lifestyle of the teachers/staffs, students, and school committees was good enough, but finding reflected the obtained data only in the period of this research at a certain point of observation. This result indicated that the healthy lifestyle among students and teachers reflected that they have realized the importance of health for his/her self or for others. It needed further evaluation and sustainable monitoring to obtain optimal result on the healthy lifestyle. It would be important and useful to build collaboration between parents, teachers, students, principals, society, Health Authority, and other components in community to solve health problems in school sekolah (Larrier \& Kijai, 2012).

\section{Conclusions}

Based on the results and the discussions, the researchers concluded that: 1) index of SHDI in SMPs in Buleleng Regency had a midlow score (0.63), with value ranged from 0.51 0.78 . the school with the highest index was SMP 1 Singaraja, and the school with the lowest index was SMP Bhaktiasa Singaraja; 2) most of the schools did not involve health elements explicitly in the vision and missions; 3 ) most of the schools had limited number of programs on health with unavailability of the written reports or records of the programs, 4) the facilities and infrastructures were good enough, there were several schools that did not have warehouse, 
and also it was still difficult to control the inappropriate (non-BPOM-licensed) food products available in the cafeterias. 4) the healthy lifestyle of the schools' residents was already good especially among teachers and students.

\section{References}

Adisasmito, W., 2010. Sistem Kesehatan. Jakarta: PT. RajaGrafindo Persada.

Dharmadi, M.A., 2016. Analysis of School Health Development Index (SHDI). Kesehatan Masyarakat, 2(1).

Dharmadi, M.A., 2017. Instrumen School Health Developmen Index (SHDI). Kesehatan Masyarakat, 4(2).

Kemenkes., 2014. Rencana Strategis Kementeria Kesehatan Republik Indonesia 2015-2019. Jakarta: Kemenkes.

Ko,Y.J., Shin, S.H., 2014. Effect of Employment and Education on Preterm an Full Term Infant Mortality in Korea. Public Health Journal,
128(3).

Larrier, Y., \& Kijai, J., 2012. School Counselor Perspectives of The Barries And Facilitators Associated with Their Involvement in the Childhood Obesity Evidemic. Health Education Journal, 43(4), pp. 218-225.

Ooms, G., Marten, R., Hammonds, R., 2014. Great Expectations for WHO: a Framework Convention On Global Health to Achieve Universal Health Coverage. Public Helath Journal, 128(2).

Reis, S., \& Morris, G., 2014. Integrating Health and Enviromental Impact Analysis. Public Health Journal, 118(4).

Sridhar, D., \& Gostin, L., 2014. World Health Organization (WHO): Past, Present and Future. Public Health Journal, 128(2).

Waltona, W., \& Signalb, L., 2013. Public Policy to Promote Healthy Nutrition in Schools: Views of Policymakers. Health Education Journal, 72(3), pp. 283-291. 